

\title{
Versatile Inclusion Behaviour of a Dinitrocalix[4]arene Having Two Ester Pendants - Preparation and X-ray crystal Structures of Complexes
}

Tobias Gruber, Edwin Weber, Wilhelm Seichter, Petra Bombicz, Ingeborg Csöregh

\section{To cite this version:}

Tobias Gruber, Edwin Weber, Wilhelm Seichter, Petra Bombicz, Ingeborg Csöregh. Versatile Inclusion Behaviour of a Dinitrocalix[4]arene Having Two Ester Pendants - Preparation and Xray crystal Structures of Complexes. Supramolecular Chemistry, 2006, 18 (06), pp.537-547. 10.1080/10610270600847040 . hal-00513481

\section{HAL Id: hal-00513481 \\ https://hal.science/hal-00513481}

Submitted on 1 Sep 2010

HAL is a multi-disciplinary open access archive for the deposit and dissemination of scientific research documents, whether they are published or not. The documents may come from teaching and research institutions in France or abroad, or from public or private research centers.
L'archive ouverte pluridisciplinaire HAL, est destinée au dépôt et à la diffusion de documents scientifiques de niveau recherche, publiés ou non, émanant des établissements d'enseignement et de recherche français ou étrangers, des laboratoires publics ou privés. 


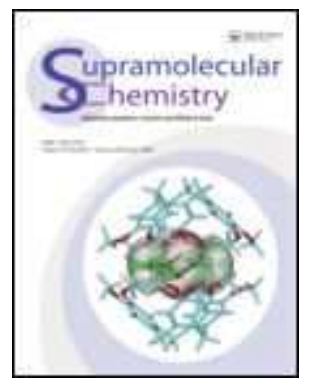

\section{Versatile Inclusion Behaviour of a Dinitrocalix[4]arene Having Two Ester Pendants - Preparation and X-ray crystal Structures of Complexes}

\begin{tabular}{|c|c|}
\hline Journal: & Supramolecular Chemistry \\
\hline Manuscript ID: & GSCH-2006-0008.R1 \\
\hline Manuscript Type: & Full Paper \\
\hline $\begin{array}{r}\text { Date Submitted by the } \\
\text { Author: }\end{array}$ & 10-May-2006 \\
\hline Complete List of Authors: & $\begin{array}{l}\text { Gruber, Tobias; TU-Bergakademie, Organische Chemie } \\
\text { Weber, Edwin; TU Bergakademie Freiberg, Organische Chemie } \\
\text { Seichter, Wilhelm; TU-Bergakademie Freiberg; TU-Bergakademie, } \\
\text { Organische Chemie } \\
\text { Bombicz, Petra; Chemical Research Center, Structural Chemistry } \\
\text { Csöregh, Ingeborg; Stockholm University, Structural Chemistry; TU } \\
\text { Bergakademie Freiberg, Organische Chemie }\end{array}$ \\
\hline Keywords: & $\begin{array}{l}\text { Calixarene host, Organic guests, Crystalline inclusion compounds, } \\
\text { Supramolecular interactions, X-ray crystal structures }\end{array}$ \\
\hline
\end{tabular}

\section{(5) ScholarONE \\ Manuscript Central}


Versatile Inclusion Behaviour of a Dinitrocalix[4] arene Having

Two Ester Pendants - Preparation and X-ray Crystal Structures of Complexes

\section{TOBIAS GRUBER ${ }^{\mathrm{a}}$, EDWIN WEBER $^{\mathrm{a}, *}$, WILHELM SEICHTER ${ }^{\mathrm{a}}$, PETRA $^{*}$} BOMBICZ $^{\mathrm{b}}$ and INGEBORG CSÖREGH ${ }^{\mathrm{c}, *}$

${ }^{a}$ Institut für Organische Chemie, Technische Universität Bergakademie Freiberg, Leipziger Str. 29, D-09596 Freiberg/Sachs., Germany;

${ }^{b}$ Institute of Structural Chemistry, Chemical Research Center, Hungarian Academy of Sciences, P. O. Box 17, H-1525 Budapest, Hungary;

${ }^{c}$ Department of Structural Chemistry, Arrhenius Laboratory, Stockholm University, S10691 Stockholm, Sweden

"Corresponding authors: Edwin Weber: Fax: +49-37-31-70, E-mail: edwin.weber@chemie.tu-freiberg.de; and Ingeborg Csöregh: FAX: +46-8-163118, Email: ics@struc.su.se. 
Abstract. An upper-rim dinitro-substituted calix[4]arene possessing two lower-rim ethyl ester pendant groups (1) has been shown to form solid inclusion compounds with acetone (1:1) (1a), DMF (1:1) (1b), DMSO (1:1) (1c) and $n$-BuOH (2:1) (1d). X-ray crystal structures of the four complexes $\mathbf{1 a}-\mathbf{d}$ are reported and comparatively discussed, including isostructurality calculations. Although the solid-state conformation of the dinitrocalix[4]arene moiety, stabilized by two intramolecular $\mathrm{O}-\mathrm{H} \cdots \mathrm{O}$ bonds, is maintained in the four inclusion compounds, and all four co-crystals have similar unit cell dimensions and identical space group symmetries, only three of them $(\mathbf{1 a}-\mathbf{c})$ are homostructural. Depending on the nature of the guest molecule, either the upper or the lower-rim site of the calixarene is involved in the complexation, demonstrating either cavitate-or clathrate-type of supramolecular interactions respectively. Moreover, due to the different guest recognition modes, the calixarene host in $\mathbf{1 d}$ is rotated through a noncrystallographic virtual rotation of $180^{\circ}$ within the unit cell, in relation to the host molecules in each of the other three homostructural compounds 1a-c, thus giving rise to supramolecular morphotropism - to our knowledge the first case ever described,

Keywords: Calixarene host; Organic guests; Crystalline inclusion compounds; Supramolecular interactions; X-ray crystal structures; Isostructurality calculations; Morphotropism. 
1

2

3

4

5

6

7

8

9

\section{INTRODUCTION}

After the macrocyclic crown type compounds [1,2] and the cyclodextrins [3], cyclic phenol-formaldehyde oligomers, known as calixarenes [4], are described as being the Deleted: oligomers of phenols third generation of supramolecular compounds [5]. Due to their rather simple preparation and unique cavity structure, including functionalized derivatives at both the lower and upper rims of the calix ring framework, they have been widely used in supramolecular chemistry $[6,7]$. Apart from providing an excellent design platform, molecular recognition to yield particular host-guest compounds is perhaps the most important aspect. Complexes of this kind have been prepared in great variety, involving modified calixarene hosts and different organic guests [8]. Crystal structures have demonstrated specific modes of supramolecular interactions and topology, with the guest molecules located at different sites of the calixarene framework or being interstitially accommodated in the crystal lattice [9]. Nevertheless, systematic and/or comparative studies, using X-ray diffraction methods on single crystals, may further extend our knowledge on the chemistry of the calixarene complexes, in particular when an individual calixarene is the host for different organic guests. Such a comparative series of compounds is described here, reporting the preparation, X-ray crystal structures and isostructurality calculations [10-12] of four inclusion species formed by calix[4]arene 1 (Scheme 1) and various guest solvents, such as acetone, dimethyl formamide (DMF), dimethyl sulfoxide (DMSO) and butan-1-ol ( $n$-BuOH)

\section{RESULTS AND DISCUSSION}

Synthesis

The host compound $\mathbf{1}$ (Scheme 1) was prepared in three steps from conventional tetra-tbutylcalix[4]arene as the starting compound [13]. The synthesis followed a known 
synthetis route [14] via common dealkylation, reaction with ethyl bromoacetate, and nitration. A total yield of $31 \%$ was obtained for the whole process. The inclusion compounds 1a-d (Scheme 1) were obtained by recrystallization of $\mathbf{1}$ from the respective guest solvent.

\section{Crystallographic Description of the Structures}

The four inclusion crystals, namely 1·acetone (1:1) (1a), 1·DMF (1:1) (1b), 1·DMSO $(1: 1)(\mathbf{1 c})$ and $\mathbf{1} \cdot n-\mathrm{BuOH}(2: 1)(\mathbf{1 d})$, have been studied using X-ray diffraction on single crystals. Perspective views of the host-guest units, together with packing diagrams of the respective compounds, are shown in Figures 1-7. Crystallographic data, selected conformational parameters and hydrogen bond geometries are listed in Tables I, II and III, respectively. Results of the crystal-packing and isostructurality calculations are presented in Tables IV-V, and Figure 8 shows the location of the calixarene host $\mathbf{1}$ in the different unit cells of $\mathbf{1 a}=\mathbf{d}$.

The four inclusion crystals of $\mathbf{1}$ proved to have similar unit cell dimensions (Table I) and identical space group symmetries (monoclinic $P 2_{1} / n$ ), indicating a close relationship between them. However, the host-guest ratio is $1: 1$ in three compounds (1a-c), containing non-protic polar guests (such as acetone, DMF and DMSO), but 2:1 in the fourth complex (1d), comprising the protic $n$ - $\mathrm{BuOH}$ solvent. This latter observation hinted at the possibility of a different organization for the $\mathbf{1 d}$ crystal in comparison with the other three related compounds, and this could be proved by the structural investigations.

The calix[4]arene ring adopts similar pinched cone conformations [15] in its present complexes (Table II), which are stabilized by two intramolecular hydrogen Deleted: is bonds between the phenolic hydrogens and the adjacent ether oxygens (Table III). The 
interplanar angles, formed by the pairs of phenyl rings with opposite locations, i.e. A/C and B/D (Scheme 1, Table II), indicate asymmetric ring shapes. The solid-state conformations of the two relatively bulky ester groups, located opposite to each other at the lower rim of each calix[4]arene, may vary: usually one of them is more extended than the other [Figures 1(a)-(c) and 5, Table II]. It is worth noting that the ester substituents exhibit high mobility and/or disorder in the crystals at room temperature ( $c f$. the atomic displacement ellipsoids), which could only be resolved into distinct disorder sites in the case of 1d (see more details in the experimental section). Moreover, the calix[4]arene ring shows a slightly more distorted cone conformation in 1d (Fig. 5) than in compounds 1a-c (see below). The X-ray analyses revealed differences also in the accommodation of guest molecules. The non-protic solvents, such as acetone, DMF and DMSO, are located in the elliptical upper-rim cavity of the calix[4]arene host [Figures 1(a)-(c)], whereas the guest alcohol in $\mathbf{1 d}$ is located on a crystallographic inversion centre near to the lower rim of the host molecule, and has an conventional O$\mathrm{H} \cdots \mathrm{O}$ hydrogen bond connection to the host ester oxygen $\mathrm{O}(30)$ (Figure 5, Table III). Since the $n$-butanol molecule is not centrosymmetric, at least two symmetry-related disorder sites must be assumed for the guest alcohol in order to satisfy the crystal symmetry requirements. The realized guest disorder model (Fig. 6) comprises two aliphatic chains with common terminal oxygen positions at both ends. Each chain has crystallographic inversion symmetry and can be seen as a superposition of two centrosymmetrically-related butanol disorder sites with overlapping carbon positions (see more details in the experimental section).

The interaction forces between the calixarene host and the non-protic guest molecules, i.e. acetone, DMF and DMSO, seem to be relatively weak (Table III). Since the calixarene $\mathrm{OH}$ groups are engaged in intramolecular $\mathrm{H}$-bonds, no $\mathrm{O}-\mathrm{H} \cdots \mathrm{O}$ interactions are observed between host and guest molecules in compounds 1a-c. 
Instead, the guest oxygens with pronounced proton acceptor ability seem to be involved in $\mathrm{C}-\mathrm{H} \cdots \mathrm{O}$ interactions [16] with one or two of the methylene groups of the ethyl ester substituents of neighbouring host molecules (Table III). In addition, potential C-H $\cdots \pi$ interactions [17-19] have also been detected, each one involving a guest methyl group and aryl $\pi$-electrons of an adjacent host phenyl ring (Table III). C-H $\cdots \mathrm{O}$ contacts [16] have been observed also between the calix[4]arene molecules. It is worth mentioning that, although the pendant ester chains of the host molecules contain potent hydrogen bond acceptors, the oxygens of the nitro groups seem to be preferred in the inter-host $\mathrm{C}-\mathrm{H} \cdots \mathrm{O}$ connections in crystals 1a-c (Table III). Inclusion of the alcoholic guest in 1d, on the other hand, makes host-guest $\mathrm{O}-\mathrm{H} \ldots \mathrm{O}$ bonds possible (Table III). The BuOH guest is held in cavities between the calix[4]arene molecules, strategically located between two ester substituents of two hosts. In this way host-guest O-H...O bond connections can be established by the butanol hydroxyl group in either of its two symmetry-related disorder sites. At the same time, the space in the inter-host cavities, accessible to the solvent molecules, is big enough to allow static disorder for the butanol guest (Table IV). The host framework in 1d, just as those of 1a-c, is held together by weaker $\mathrm{C}-\mathrm{H} \cdots \mathrm{O}[16]$ and possible $\mathrm{C}-\mathrm{H} \cdots \pi$ [17-19] interactions. We noted that the most heavily disordered host ester methyl group [at $\mathrm{C}(38)$ ] also seems to be involved in possible hydrogen-bond type interactions with phenyl $\pi$-electrons of neighbouring host molecules (Table III). This observation suggests that the majority of the assumed $\mathrm{C}_{-}$ $\mathrm{H} \cdots \pi$ interactions in Table III are relatively weak and uncertain. The possibility that some of the noted shorter distances (particularly those with $\mathrm{C}_{-} \mathrm{H} \cdots \pi$ angles near to $120^{\circ}$ ) may be consequences of close packing, yielding accidental proximity of methyl and

Deleted: Worth

Deleted: ,

Deleted: -

Deleted: host-guest

Deleted: host-guest

\section{Deleted: -}

Deleted: ,

Deleted: also

Deleted: hydrogen

\begin{tabular}{|l|}
\hline Deleted: \\
\hline Deleted: - \\
\hline Deleted: \\
\hline
\end{tabular}

Deleted: -

Deleted: the

Deleted: the involved phenyl groups, can not completely ruled out. 
Comparison of the crystal structures of compounds 1a-d indicates that ${ }_{2}$ in addition to the geometric features of the bulky calix[4]arene host, the host-guest interaction modes also play an important role in the determination of the packing relations. Accordingly, host $\mathbf{1}$ was found to exhibit comparable conformations, with the shape of a pinched cone [15], in its four inclusion crystals (1a-d), although the calix[4]arene ring is slightly more distorted in $\mathbf{1 d}$ than in the three related compounds (1a-c, Table II). However, inclusion of the protic $n$-BuOH molecule affected not only the host conformation, but it also led to a substantial change of the packing relations in 1d, as compared to those containing non-protic guests (i.e. 1a-c). At the same time, replacement of the acetone guest by other non-protic solvents of enhanced polarity, such as DMF or DMSO, did not affect the packing mode of the respective inclusion compound significantly. It is interesting to note, that the protruding ethyl ester chains in 1a-c were found to assemble in a manner that is characteristic for hydrophobic rather than polar groups (Figures 2-4).

The presence of a solvent possessing strong proton donor ability in 1d leads to the packing arrangement shown in Fig. 7. In $\mathbf{1} \mathbf{a}-\mathbf{c}_{2} \mathrm{C}_{\text {methyl }}-\mathrm{H}_{-} \cdots \pi_{\mathrm{aryl}}$ connections are observed between host and guest molecules, whereas in 1d only the calix[4]arene molecules takes part in possible $\mathrm{C}-\mathrm{H} \cdots \pi$ interactions, involving both ester terminal groups, also the statically disordered one at its both disorder sites [i.e. $\mathrm{C}(38)$ and $\left.\mathrm{C}\left(38^{\prime}\right)\right]$ (Table III, Fig. 5). The latter ester chain is directed towards the upper-rim cavity of the neighbouring molecule, related by the symmetry $0.5-x,{ }_{-}-0.5+y, y_{-} 0.5+z$. Through the $\mathrm{C}-$ $H \cdots \pi$ interactions, involving the $\mathrm{C}(38)$ methyl group (Table III), supramolecular strands are created, which run along the crystallographic $b_{*}$ axis. Interestingly, similar observations have been made earlier in a related inclusion crystal of host $\mathbf{1}$, containing water as guest [20].
Deleted: 1a

Deleted: -

Deleted: ,

Deleted: also

Deleted: host-guest

Deleted: a

\section{Deleted: -}

Deleted: -

Deleted: also

Deleted:

Deleted: -

Deleted:

\begin{tabular}{l} 
Deleted: - \\
Deleted: \\
\hline Deleted: which \\
Deleted: - \\
Formatted: Highlight \\
Deleted: at \\
Deleted: has \\
Deleted: - \\
\hline
\end{tabular}

Deleted: s

\section{Deleted:}

Deleted: a

Deleted:

Deleted: II

\section{Deleted: II}

II 


\section{Isostructurality Calculations}

\section{।}

In order to estimate the degree of isostructurality of the host frameworks in 1a-d, and to examine the influence of the guest molecules on the solid-state conformation of host $\mathbf{1}$, isostructurality calculations were carried out comparing the four inclusion crystals twoby-two. The cell similarity indices $(\pi)$ as well as the isostructurality $[I(s)]$ and molecular isometricity indices $[I(m)]$ were estimated for each pair of compounds [10-12], and are listed in Table $\mathrm{V}$. The cell similarity index $(\pi)$ was calculated as $\pi=\left[(a+b+c) /\left(a^{\prime}+b^{\prime}+c^{\prime}\right)-1\right]$, where $a, b, c$, and $a^{\prime}, b^{\prime} c^{\prime}$ are the orthogonalized lattice parameters of the compared crystals. In the event of great similarity of the two unit cells, the value of $\pi$ is close to zero $[10,12]$. Despite the difference in the host-guest stoichiometries (Table I), the calculated cell similarity indices (ranging between 0.008 and 0.034 ) indicate only marginal differences in the unit cell dimensions of 1a-d, with the 1d cell, containing $n$ - $\mathrm{BuOH}_{2}$ being the most deviating one. Concerning the three compounds with identical host-guest ratio (i.e. 1a-c), increasing size of the guest molecule seems to lead to a larger volume for the unit cell.

Due to the static disorder in one of the pendant ester chains in 1d two solid-state conformations of the $\mathbf{1 d}$ host, namely $\mathbf{1 d 1}$ [including C(37)-C(38)] and $\mathbf{1 d 2}$ [containing $\left.\mathrm{C}\left(37^{\prime}\right)-\mathrm{C}\left(38^{\prime}\right)\right]$ were compared with the host conformations in 1a-c $\mathbf{c}$ and also with each other (Table V). In the calculation of the isostructurality $[I(s)]$ and the molecular isometricity indices $[I(m)]_{2}$ two comparisons were performed for each pair of compounds: either only the more rigid parts of the calix[4]arene molecule, containing 38 non-hydrogen atoms (without the ester substituents), were compared, or else all 50 heavy atoms of each host were fitted (Table V). In the estimation of the isostructurality $[I(s)]$ parameters [10-12] both the differences in molecular geometry and the positional differences $\left(\Delta R_{i}\right)$, caused by rotational and/or translational operations, are taken into

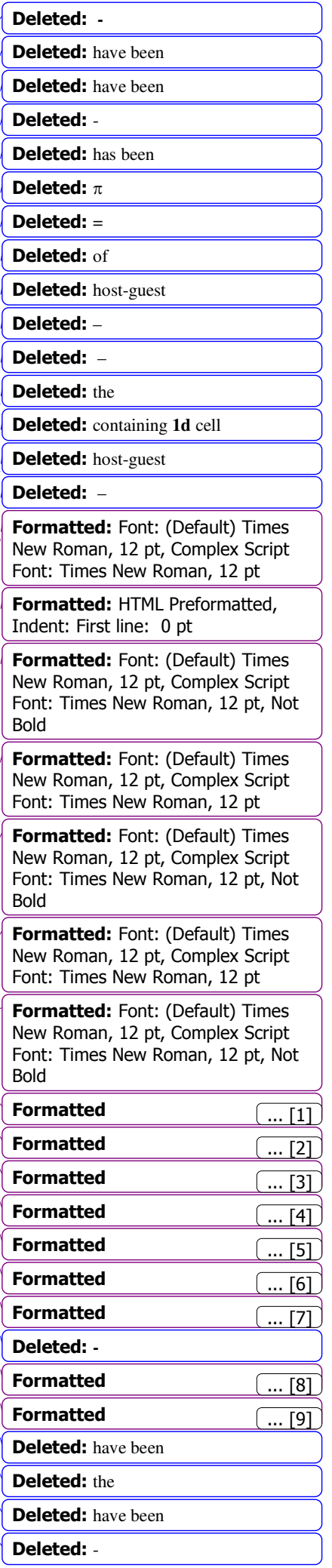


account. On the other hand, using refined $\Delta R_{i}$ values from a full or partial least-squares fitting of the positions occupied by corresponding atoms in the two superimposed structures leads to a new index, termed isometricity index $[I(m)]$, which is seen as a direct measure of the degree of approximate isomorphism of the two compared molecules. The calculations indicate that the inclusion compounds 1a-c can be described as more or less homostructural, with reference to both the conformation of the host calix[4]arene molecules and their location in the unit cells, although the calculated $I(s)$ values are considerably lower and exhibit wider scatter than the corresponding $I(m)$ indices (Table V). Nevertheless, the host framework in $\mathbf{1 d}$ is not isostructural with any of the three previous ones (in 1a-c), and due to the different location and orientation of the calix[4]arene host within the $\mathbf{1 d}$ unit cell, no reasonable $I(s)$ indices could be calculated for pairs of compounds involving the 1d host molecule. Furthermore, although the $I(m)$ indices, estimated by comparing the more rigid part of the molecules (38 non-hydrogen atoms), indicated modest degrees of molecular isomorphism, inclusion of the pendant ester groups in the calculations led to drastically decreased $I(\mathrm{~m})$ values (Table V). Hence, according to the isostructurality calculations, inclusion of the protic, elongated butanol guest affects the form of the host molecule, in general, and the conformation of the flexible pendant ester chains, in particular. In addition, careful comparison of any of the homostructural host frameworks in 1a-c on the one hand, and that of $\mathbf{1 d}$ on the other, yielded an interesting observation: the location of the calix[4]arene molecule in the $\mathbf{1 d}$ unit cell seems to be related to the host position in each of the 1a-c complexes by a virtual, non-crystallographic two-fold $\left(180^{\circ}\right)$ rotation ( 8). Accordingly, the host framework in 1d has a morphotropic relation [21] to each of the three others in 1a-c. In general, crystals exhibiting frameworks differing by one or two non-crystallographic virtual rotation(s) of the common motifs, or the whole pattern, may be denoted as 'morphotropic'. According to the literature [21], closely related

\begin{tabular}{|c|c|}
\hline Deleted: - & \\
\hline Formatted & $\ldots[10]$ \\
\hline Formatted & $\ldots[11]$ \\
\hline Deleted: hor & \\
\hline Deleted: e & \\
\hline Deleted: wit & \\
\hline Formatted & $\ldots[12]$ \\
\hline Formatted & $\ldots[13]$ \\
\hline Deleted: - & \\
\hline Formatted & $\ldots[14]$ \\
\hline Formatted & $\ldots[15]$ \\
\hline Formatted & $\ldots[16]$ \\
\hline Formatted & $\ldots[17]$ \\
\hline Formatted & $\ldots[18]$ \\
\hline Formatted & $\ldots[19]$ \\
\hline Deleted: & \\
\hline Comment [ & $\ldots[20]$ \\
\hline Deleted: $\mathrm{He}$ & $\ldots[21]$ \\
\hline Formatted & $\ldots[22]$ \\
\hline Deleted: , pa & $\ldots[23]$ \\
\hline Deleted: . I & \\
\hline Formatted & $\ldots[24]$ \\
\hline Formatted & $\ldots[25]$ \\
\hline Formatted & $\ldots[26]$ \\
\hline Deleted: - & \\
\hline Formatted & $\ldots[27]$ \\
\hline Formatted & $\ldots[28]$ \\
\hline Formatted & $\ldots[29]$ \\
\hline Formatted & $\ldots[30]$ \\
\hline Formatted & $\ldots[31]$ \\
\hline Formatted & $\ldots[32]$ \\
\hline Formatted & $\ldots[33]$ \\
\hline Formatted & $\ldots[34]$ \\
\hline Deleted: - & \\
\hline Formatted & $\ldots$ [35] \\
\hline Formatted & $\ldots[36]$ \\
\hline Formatted & $\ldots$ [37] \\
\hline Deleted: any & \\
\hline Formatted & $\ldots[38]$ \\
\hline Formatted & $\ldots[39]$ \\
\hline Formatted & $\ldots[40]$ \\
\hline Formatted & $\ldots[41]$ \\
\hline Formatted & $\ldots[42]$ \\
\hline Deleted: - & \\
\hline Formatted & $\ldots[43]$ \\
\hline Formatted & $\ldots[44]$ \\
\hline Formatted & [45] \\
\hline
\end{tabular}


compounds (e.g. stereoisomers, homologues), which crystallize with analogous unit cell dimensions but are not isostructural, are good candidates for morphotropism. The noncrystallographic virtual rotation is a possible consequence of the requirement of close packing, since rotation of the common motif may transform one pattern with lower density into another with denser packing. Comparison of the estimated packing coefficients in 1a-d (Table IV), suggests that it may be valid also in the present case. Isostructurality and morphotropy are inseparable conceptions. In case of these four structures the cells hardly differ but the presence of the different guest molecules brings changes in the placement of the calix[4]arene host molecule in the unit cell and in the distortion of the host molecule. Thus morphotropic change signs the end of isoctructurality keeping molecular isometricity in the same time. However, there is a unique feature of the observed morphotropism in the present calix[4]arene inclusion compounds: the rotation of the $\mathbf{1 d}$ host in the unit cell is a consequence of the change in the supramolecular (host-guest) recognition mode. The shift of the guest characteristic from polar non-protic (acetone, DMF, DMSO) to polar protic $(n-\mathrm{BuOH})$ changes the host-guest interaction mode and also the shape of the H-bonded host-guest supramolecular entity, which in turn initiates a non-crystallographic rotation of the calix[4]arene molecule, in all probability in order to reach acceptable packing density for the alcoholic inclusion crystal (Table IV). Accordingly, the present calix[4]arene inclusion compounds give an example of supramolecular morphotropism, which has not earlier been described in the literature.

\section{CONCLUSION}

|

An upper-rim dinitro-substituted calix[4]arene possessing two lower-rim ethyl ester pendant groups (1) has been shown to form inclusion crystals with acetone (1:1) (1a), 
DMF (1:1) (1b), DMSO (1:1) (1c) and $n-\mathrm{BuOH}(2: 1)$ (1d). Although the four cocrystals have similar unit cell dimensions and identical space group symmetries, only compounds 1a-c proved to be homostructural. A shift of the guest characteristic from polar non-protic (acetone, DMF, DMSO) to polar protic $(n-\mathrm{BuOH})$ changes the mode of guest recognition, and also affects the shape of the host-guest supramolecular entity. Accordingly, the upper rim of the host is involved in the complexation of the non-protic guests, whereas the protic butanol molecule is hydrogen bonded to a lower-rim site, thus giving rise to cavitate and clathrate type of supramolecular interactions, respectively. As a consequence, the calixarene host in $\mathbf{1 d}$ is rotated through a non-crystallographic virtual rotation of $180^{\circ}$ within the unit cell, in relation to the host molecules in the other three compounds 1a-c, thus leading to supramolecular morphotropism - to our knowledge the first case ever described,

In summary, the present calix[4]arene (1) is both a useful source for synthesis of more elaborate calixarenes, due to the potential transformations of the lower and upperrim substituents $[14,23,24]$, and also a versatile host compound owing to the particular inclusion behaviour. Furthermore, the molecular conformation of the calix[4]arene skeleton is stabilized by two relatively strong intramolecular $\mathrm{O}-\mathrm{H} \cdots \mathrm{O}$ bridges, which remained unchanged also in the presence of solvent molecules with rather strong proton donor and/or acceptor ability, thus providing a largely foreseeable conformation for the derivatives of the calix[4]arene molecule $\mathbf{1}$, which is a favourable property in host design.

\section{EXPERIMENTAL}

\section{Preparation of Compounds}


The calixarene host compound $\mathbf{1}$ was synthesized from 5,11,17,23-tetra-tert-butyl25,26,27,28-tetrahydroxycalix[4]arene [13] according to the literature [14]. Crystals of the inclusion compounds 1a-d were prepared by slow crystallization of $\mathbf{1}$ from the respective guest solvent.

\section{X-ray Crystallography}

A CAD-4 diffractometer was employed for data collection from the 1·acetone (1:1) (19) inclusion compound, using the $\omega-2 \theta$ scan mode. X-ray intensity data from the inclusion compounds 1·DMF (1:1) (1b), 1·DMSO (1:1) (1c) and 1·n-BuOH (2:1) (1d) were collected on a STOE Imaging Plate Diffraction System (IPDS) equipped with a rotating anode, using area detector scans [24]. The net intensities were corrected for Lorentz and polarization effects $[24,25]$. Preliminary structure models were derived by application of direct methods [26] and were refined by full-matrix least-squares (LS) calculations based on $F^{2}$ values for all unique reflections [26]. The non-hydrogen atom positions in all compounds, the $\mathrm{S}$ disorder sites in 1c, and the host $\mathrm{C}$ disorder sites in 1d were refined anisotropically, whereas the partially occupied guest carbon positions in 1d (see below) were treated isotropically. The carbon-bonded $\mathrm{H}$ atoms were included in the models in calculated positions [26], whereas the hydroxy hydrogen positions were extracted from difference electron density maps and were held riding on their parent oxygens during the subsequent calculations. The LS calculations indicated that various groups attached to the calixarene skeleton, such as the nitro groups and the ethyl ester pendant arms, exhibit more or less high mobility and/or disorder in all four compounds ( $U_{\text {eq }}$ values range between 0.1 and $0.4 \AA^{2}$ ). However, only in one case was the partial host disorder resolved into distinct disorder sites. Accordingly, two partially occupied sites were realized for one of the terminal ethyl groups [namely C(37)_C(38)] in 1d

Deleted: d

Deleted:

Deleted:

Deleted:

Deleted:

Deleted: -

Deleted: i.e. 
1
(Figure 5), with the site occupation factors (sof's) 0.675 (unprimed positions) and 0.325 (primed positions), respectively. Also the loosely bonded guest entities show dynamic, and in some cases also static, disorder. The DMSO guest in 1c, for example, occupies two partly overlapping disorder sites with $65 \%$ [including $\mathrm{S}(1)$ ] and $35 \%$ [including $\mathrm{S}(2)]$ probability [Fig. 1(c)]. Furthermore, in spite of the observed host-guest $\mathrm{O}(\mathrm{H}) \cdots \mathrm{O}$ hydrogen bond interaction in $\mathbf{1 d}$ (Table III), the $n$ - $\mathrm{BuOH}$ guest is heavily disordered, thus yielding a relatively smooth electron density distribution. This alcoholic guest proved to be located on a crystallographic inversion centre, although the $n$-butanol molecule is not centrosymmetric. The approximate guest disorder model (Fig. 6) comprises two aliphatic chains with common terminal oxygen positions at both ends. Each chain has crystallographic inversion symmetry and can be seen as a superposition of two centrosymmetrically related butanol disorder sites with overlapping carbon positions. The major (unprimed) and minor (primed) $\mathrm{C}$ atoms have roughly $2 / 3$ and $1 / 3$ site occupation probability, respectively, whereas each terminal oxygen atom has sof $=0.50$ due to the crystal symmetry requirement. The disorder model, including calculated major guest $\mathrm{H}$ disorder sites, has been refined with distance constraints.

Crystal data and experimental parameters are summarized in Table I. Crystallographic data for compounds 1a-1d have been deposited with the Cambridge Crystallographic Data Centre with CCDC numbers 292018-292021, respectively. Copies can be obtained, free of charge, on application to CCDC, 12 Union Road, Cambridge CB2 1EZ, UK (Fax: +44-1223-336033, E-mail: deposit@ccdc.cam.ac.uk).

\section{Acknowledgements}


The authors are indebted to A. Kálmán (Chemical Research Center, Budapest) for his constructive advice and valuable comments concerning isostructurality and Deleted: isotructurality morphotropism. Financial support from the German Federal Ministry of Economics and Labour (BMWA, grant No. 16IN0217 "ChemoChips"), and from the Hungarian research grants OTKA T042642 and T049712, is gratefully acknowledged

\begin{tabular}{|l|}
\hline Formatted: Highlight \\
\hline Deleted: IN3593 \\
\hline Deleted: $\mathbb{I}$ \\
$\mathbb{I}$ \\
$\mathbb{I}$ \\
$\mathbb{I}$ \\
$\mathbb{I}$ \\
$\mathbb{I}$ \\
\hline
\end{tabular}


1

2

3

4

5

6

7

8

9

\section{References}

[1] Patai, S., Rappoport, Z., Eds. Crown Ethers and Analogs; Wiley: Chichester, 1989.

[2] Gokel, G. Crown Ethers and Cryptands, Monographs in Supramolecular Chemistry; Royal Society of Chemistry: Cambridge, UK, 1991; Vol. 3.

[3] Szejtli, J, Osa, T., Eds. Comprehensive Supramolecular Chemistry; Elsevier: Oxford, 1996; Vol. 3.

[4] Gutsche, C. D. Calixarenes, Monographs in Supramolecular Chemistry; Royal Society of Chemistry: Cambridge, UK, 1989; Vol. 1.

[5] Weber, E., Vögtle, F. In Comprehensive Supramolecular Chemistry; Vögtle, F., Ed.; Elsevier: Oxford, 1996; Vol. 2, p 1.

[6] Vicens, J., Böhmer, V., Eds. Calixarenes - A versatile Class of Macrocyclic Compounds; Kluwer: Dordrecht, 1991.

[7] Gutsche, C. D. Calixarenes Revisited, Monographs in Supramolecular Chemistry; Royal Society of Chemistry: Cambridge, UK, 1998; Vol. 6.

[8] Mandolini, L., Ungaro, R., Eds. Calixarenes in Action; Imperial College Press: London, 2000.

[9] _ Asfari, M.-Z., Böhmer, V., Harrowfield, J., Vicens, J.2 Eds. Calixarenes 2001; Kluwer: Dordrecht, 2001.

[10] Kálmán, A., Párkányi, L., Argay, G. Acta Crystallogr. Sect. B 1993, 49, 1039.

[11] Kálmán, A. In Fundamental Principles of Molecular Modeling; Gans, W., Ed.; Plenum Press: New York, 1996; p. 209. 
[12] Kálmán, A., Párkányi, L. In Advances in Molecular Structure Research; Hargittai, M., Hargittai, I., Eds.; JAI Press: Greenwich, Conn., 1997; Vol.3, p. 189.

[13] Gutsche, C. D., Iqbal, M., Stewart, D. J. Org. Chem. 1986, 51, 742.

[14] Rudkevich, D. M., Verboom, W., Reinhoudt, D. N. J. Org. Chem. 1994, 59, 3683.

[15] Scheerder, J., Vreekamp, R. H., Engbersen, J. F. J., Verboom, W., van Duynhoven, J. P. M., Reinhoudt, D. N. J. Org. Chem. 1996, 61, 3476.

[16] Desiraju, G. R., Steiner, T. The Weak Hydrogen Bond in Chemistry and Structural Biology; Oxford University Press: Oxford, 1999.

[17] Nishio, M., Hirota, M., Umezawa, Y. The $C H / \pi$ Interaction - Evidence, Nature and Consequences; Wiley-VCH: New York, 1998.

[18] Nishio, M. CrystEngComm 2004, 6, 130.

[19] Nishio, M. In Encyclopedia of Supramolecular Chemistry; Atwood, J. L., Steed, J. W., Eds.; Marcel Dekker: New York, 2004; p 1576.

[20] Lu, H., Li, B., Lin, Y., Xu, Z. J. Incl. Phenom. 2003, 45, 9.

[21] Kálmán, A. Acta Crystallogr. 2005, B61, 536 (and references therein).

[22] Tomapatanaget, B., Tuntulani, T. Tetrahedron Lett. 2001, 42, 8105.

[23] Tomapatanaget, B., Tuntulani, T., Chailapakul, O. Org. Lett. 2003, 5, 1539.

[24] Stoe \& Cie GmbH 1997 (Publications 4805-014).

16 
1

2

3

4

5

6

7

8

9

10

11

12

13

14

15

16

17

18

19

20

21

22

23

24

25

26

27

28

29

30

31

32

33

34

35

36

37

38

39

40

41

42

43

44

45

46

47

48

49

50

51

52

53

54

55

56

57

58

59

60

[25] Harms, K. XCAD. Program for the Reduction of CAD-4 Diffractometer Data, University of Marburg: Marburg, 1997.

[26] Sheldrick, G. M. SHELX-97. Program for Crystal Structure Solution and Refinement, University of Göttingen: Göttingen, 1997.

[27] Spek, A. L. PLATON - A multipurpose crystallographic tool. Utrecht University, The Netherlands, 2002.

Deleted: numune Page Break 
Table I Crystal data and selected details of the data collection and refinement calculations of compounds 1a-d.

\begin{tabular}{|c|c|c|c|c|}
\hline Compound & 1a & 1b & 1c & 1d \\
\hline Empirical formula moiety & $\begin{array}{c}\mathrm{C}_{36} \mathrm{H}_{34} \mathrm{~N}_{2} \mathrm{O}_{12} \cdot \\
\mathrm{C}_{3} \mathrm{H}_{6} \mathrm{O}\end{array}$ & $\begin{array}{c}\mathrm{C}_{36} \mathrm{H}_{34} \mathrm{~N}_{2} \mathrm{O}_{12} \cdot \\
\mathrm{C}_{3} \mathrm{H}_{7} \mathrm{NO}\end{array}$ & $\begin{array}{c}\mathrm{C}_{36} \mathrm{H}_{34} \mathrm{~N}_{2} \mathrm{O}_{12} \cdot \\
\mathrm{C}_{2} \mathrm{H}_{6} \mathrm{SO}\end{array}$ & $\begin{array}{c}\mathrm{C}_{36} \mathrm{H}_{34} \mathrm{~N}_{2} \mathrm{O}_{12} \\
0.5\left(\mathrm{C}_{4} \mathrm{H}_{10} \mathrm{O}\right)\end{array}$ \\
\hline Formula weight & 744.73 & 759.75 & 764.78 & 723.71 \\
\hline Crystal system & Monoclinic & Monoclinic & Monoclinic & Monoclinic \\
\hline Space group & $P 2_{1} / \mathrm{n}$ & $P 2_{1} / \mathrm{n}$ & $P 2_{1} / \mathrm{n}$ & $P 2{ }_{1} / \mathrm{n}$ \\
\hline$a(\AA)$ & $10.332(2)$ & $10.483(1)$ & $10.288(1)$ & $10.268(1)$ \\
\hline$b(\AA)$ & $15.893(2)$ & $16.082(2)$ & $16.222(2)$ & $15.626(3)$ \\
\hline$c(\AA)$ & $22.620(5)$ & $22.593(3)$ & $22.537(3)$ & $22.520(3)$ \\
\hline$\alpha\left(^{\circ}\right)$ & 90.0 & 90.0 & 90.0 & 90.0 \\
\hline$\beta\left(^{\circ}\right)$ & $95.47(3)$ & $97.821(17)$ & $95.103(18)$ & $92.370(16)$ \\
\hline$\gamma\left({ }^{\circ}\right)$ & 90.0 & 90.0 & 90.0 & 90.0 \\
\hline$V\left(\AA^{3}\right)$ & $3697.4(13)$ & $3773.5(8)$ & $3746.3(8)$ & $3610.2(9)$ \\
\hline$Z$ & $4 \quad-$ & 4 & 4 & 4 \\
\hline$F(000)$ & 1568 & 1600 & 1608 & 1524 \\
\hline Radiation $/ \lambda(\AA)$ & $\mathrm{Cu} K \alpha / 1.54180$ & МoK $\alpha / 0.71073$ & Мо $K \alpha / 0.71073$ & МoK $\alpha / 0.71073$ \\
\hline$D_{\mathrm{c}}\left(\mathrm{Mg} \mathrm{m}^{-3}\right)$ & 1.338 & 1.337 & 1.356 & 1.332 \\
\hline$\mu\left(\mathrm{mm}^{-1}\right)$ & 0.847 & 0.101 & 0.155 & 0.100 \\
\hline \multicolumn{5}{|l|}{ Data collection } \\
\hline Temperature (K) & $298(2)$ & 293(2) & 293(2) & $293(2)$ \\
\hline No. of collected reflections & 6624 & 29334 & 28836 & 28187 \\
\hline within the $\underline{\theta}$ limits $\left({ }^{\circ}\right)$ & $3.4-65.0$ & $2.05-25.96$ & $2.11-25.97$ & $2.15-25.97-$ Deleted: $\theta$ \\
\hline Index ranges $\pm h, \pm k, \pm l$ & $0 / 12,-18 / 0,-26 / 26$ & $-12 / 12,-19 / 19,-27 / 27$ & $-12 / 12,-19 / 19,-27 / 27$ & $-11 / 12,-19 / 19,-27 / 27$ \\
\hline No. of unique $F^{2}$ values & 6251 & 7053 & 7286 & $6719 \ldots \ldots$ Deleted: - \\
\hline $\boldsymbol{R}_{\text {int }}$ & 0.026 & 0.072 & 0.078 & 0.114 \\
\hline Refinement calculations: & $\begin{array}{l}\text { full-matrix LS on all } \\
F^{2} \text { values }\end{array}$ & $\begin{array}{l}\text { full-matrix LS on all } \\
F^{2} \text { values }\end{array}$ & $\begin{array}{l}\text { full-matrix LS on all } \\
F^{2} \text { values }\end{array}$ & $\begin{array}{l}\text { full-matrix LS on all } \\
F^{2} \text { values }\end{array}$ \\
\hline No. of refined parameters & 493 & 541 & 538 & 524 \\
\hline$R\left(=\Sigma|\Delta F| / \Sigma\left|F_{\mathrm{O}}\right|\right)$ & 0.070 & 0.051 & 0.056 & 0.055 \\
\hline No. of $F$ values used $[I>2 \sigma(I)]$ & 3939 & 4379 & 3932 & 3054 \\
\hline$w R$ on all unique $F^{2}$ & 0.198 & 0.143 & 0.164 & 0.136 \\
\hline $\begin{array}{l}S\left({ }_{-}=\text {Goodness of fit on } F^{2}\right) \\
\text { Weighting expression } w^{\text {a }}\end{array}$ & $\begin{array}{l}1.106 \\
{\left[\sigma^{2}\left(F_{\mathrm{o}}{ }^{2}\right)+(0.1075 P)^{2}+\right.} \\
0.1378 P)]^{-1}\end{array}$ & $\begin{array}{l}0.997 \\
{\left[\sigma^{2}\left(F_{\mathrm{o}}{ }^{2}\right)+(0.0820 P)^{2}+\right.} \\
0.000 P)]^{-1}\end{array}$ & $\begin{array}{l}0.965 \\
{\left[\sigma^{2}\left(F_{\mathrm{o}}{ }^{2}\right)+(0.0925 P)^{2}+\right.} \\
0.000 P)]^{-1}\end{array}$ & $\begin{array}{l}0.922 \\
{\left[\sigma^{2}\left(F_{\mathrm{o}}{ }^{2}\right)+(0.0585 P)^{2}+\right.} \\
0.000 P)]^{-1}\end{array}$ \\
\hline Final $\Delta \rho_{\max } / \Delta \rho_{\min }\left(\mathrm{e}^{-} \AA^{-3}\right)$ & $0.35 /-0.29$ & $0.32 /-0.26$ & $0.41 /-0.32$ & $0.26 /-0.23$ \\
\hline
\end{tabular}

${ }^{\mathrm{a}}$ Following Sheldrick [26]. $P=\left(F_{\mathrm{o}}{ }^{2}+2 F_{\mathrm{c}}{ }^{2}\right) / 3$ 
TABLE II Selected conformational parameters of the calixarene molecule in the | complexes 1a-d.

\begin{tabular}{|c|c|c|c|c|}
\hline Compound & $1 \mathbf{a}$ & $1 \mathrm{~b}$ & $1 \mathrm{c}$ & 1d \\
\hline \multicolumn{5}{|l|}{ Interplanar angles $\left({ }^{\circ}\right)^{\mathrm{a}}$} \\
\hline $\mathrm{mpla}^{\mathrm{b}} / \mathrm{A}$ & $44.31(8)$ & $42.85(6)$ & $42.38(8)$ & $35.46(7)$ \\
\hline $\mathrm{mpla} / \mathrm{B}$ & 73.67(9) & $70.01(6)$ & $70.30(7)$ & $71.85(7)$ \\
\hline $\mathrm{mpla} / \mathrm{C}$ & $41.21(8)$ & $45.83(6)$ & $46.38(7)$ & $49.86(9)$ \\
\hline $\mathrm{mpla} / \mathrm{D}$ & $70.40(8)$ & $73.24(6)$ & $70.64(7)$ & $66.74(9)$ \\
\hline $\mathrm{A} / \mathrm{C}$ & $85.52(10)$ & $88.66(7)$ & $88.76(10)$ & $85.27(9)$ \\
\hline $\mathrm{B} / \mathrm{D}$ & 35.93(9) & $36.75(7)$ & $39.06(7)$ & $41.47(9)$ \\
\hline A ring $/ \mathrm{NO}_{2}$ group & $8.16(14)$ & $9.25(11)$ & $13.3(3)$ & $7.5(3)$ \\
\hline $\mathrm{C}$ ring/ $/ \mathrm{NO}_{2}$ group & $5.2(2)$ & $5.11(6)$ & $5.82(11)$ & $22.1(2)$ \\
\hline \multicolumn{5}{|l|}{ Torsion angles $\left({ }^{\circ}\right)$} \\
\hline $\mathrm{C}(1)-\mathrm{C}(6)-\mathrm{C}(7)-\mathrm{C}(9)$ & $74.5(4)$ & $-75.9(3)$ & $83.4(3)$ & $-75.0(3)$ \\
\hline $\mathrm{C}(6)-\mathrm{C}(7)-\mathrm{C}(9)-\mathrm{C}(8)$ & $-100.3(3)$ & $97.0(2)$ & $-106.6(3)$ & $106.9(3)$ \\
\hline$C(8)-C(13)-C(14)-C(16)$ & $108.4(3)$ & $-106.0(2)$ & $97.4(3)$ & $-97.5(3)$ \\
\hline$C(13)-C(14)-C(16)-C(15)$ & $-79.8(3)$ & $83.7(3)$ & $-76.6(3)$ & $80.6(4)$ \\
\hline$C(15)-C(20)-C(21)-C(23)$ & $74.7(4)$ & $-76.5(3)$ & $84.2(3)$ & $-86.8(3)$ \\
\hline $\mathrm{C}(20)-\mathrm{C}(21)-\mathrm{C}(23)-\mathrm{C}(22)$ & $-97.6(3)$ & 100.1(2) & $-106.7(3)$ & $100.8(3)$ \\
\hline$C(22)-C(27)-C(28)-C(2)$ & $106.6(3)$ & $-107.9(2)$ & $97.0(3)$ & $-95.8(3)$ \\
\hline$C(27)-C(28)-C(2)-C(1)$ & $-82.7(4)$ & $81.0(2)$ & $69.8(4)$ & $69.8(4)$ \\
\hline $\mathrm{C}(8)-\mathrm{O}(8)-\mathrm{C}(29)-\mathrm{C}(30)$ & $150.9(3)$ & $-119.4(2)$ & $-145.2(3)$ & $155.6(3)$ \\
\hline $\mathrm{O}(8)-\mathrm{C}(29)-\mathrm{C}(30)-\mathrm{O}(31)$ & $172.3(3)$ & $-172.3(2)$ & $-175.0(3)$ & $170.1(3)$ \\
\hline $\mathrm{C}(29)-\mathrm{C}(30)-\mathrm{O}(31)-\mathrm{C}(32)$ & $175.3(4)$ & $-178.5(3)$ & $-178.8(5)$ & $177.3(4)$ \\
\hline $\mathrm{C}(30)-\mathrm{O}(31)-\mathrm{C}(32)-\mathrm{C}(33)$ & $-174.2(5)$ & $105.3(6)$ & $176.8(8)$ & $163.0(6)$ \\
\hline $\mathrm{C}(22)-\mathrm{O}(22)-\mathrm{C}(34)-\mathrm{C}(35)$ & $148.5(3)$ & $-177.6(2)$ & $-151.4(3)$ & $125.0(3)$ \\
\hline $\mathrm{O}(22)-\mathrm{C}(34)-\mathrm{C}(35)-\mathrm{O}(36)$ & $168.2(3)$ & $174.9(2)$ & $-164.4(3)$ & $155.8(3)$ \\
\hline $\mathrm{C}(34)-\mathrm{C}(35)-\mathrm{O}(36)-\mathrm{C}(37)$ & $179.8(3)$ & $174.6(4)$ & $-173.9(3)$ & $-175.2(6)$ \\
\hline $\mathrm{C}(35)-\mathrm{O}(36)-\mathrm{C}(37)-\mathrm{C}(38)$ & $95.8(5)$ & $162.8(4)$ & $83.9(5)$ & $153.8(6)$ \\
\hline
\end{tabular}

\footnotetext{
${ }^{a}$ Aromatic rings: ring $\mathrm{A}: \mathrm{C}(1) \ldots \mathrm{C}(6)$; ring $\mathrm{B}: \mathrm{C}(8) \ldots \mathrm{C}(13)$; ring $\mathrm{C}: \mathrm{C}(15) \ldots \mathrm{C}(20)$; ring $\mathrm{D}: \mathrm{C}(22) \ldots \mathrm{C}(27)$;
}

${ }^{\mathrm{b}}$ Best plane through atoms $\mathrm{C}(7), \mathrm{C}(14), \mathrm{C}(21)$ and $\mathrm{C}(28)$. 
TABLE III Distances and angles of possible hydrogen-bond type interactions, observed for compounds 1a-d.

Deleted: hydrogen

Deleted: -

${ }^{a}$ Centroid means the centre of gravity of the respective aromatic ring, such as ring A: C(1)...C(6); ring B:

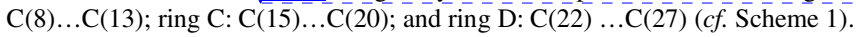

\begin{tabular}{|c|c|c|c|c|}
\hline$x, y, z$ & 1.01 & $2.739(3)$ & 1.78 & 156 \\
\hline$x, y, z$ & 0.93 & $2.766(3)$ & 1.94 & 148 \\
\hline $0.5-x, 0.5+y,-0.5-z$ & 0.93 & $3.440(5)$ & 2.53 & 167 \\
\hline $1.5-x, 0.5+y,-0.5-z$ & 0.93 & $3.339(4)$ & 2.47 & 155 \\
\hline $2-x, 2-y,-z$ & 0.97 & $3.404(5)$ & 2.47 & 163 \\
\hline $1-x, 2-y,-z$ & 0.97 & $3.338(5)$ & 2.41 & 161 \\
\hline $1.5-x,-0.5+y,-0.5-z$ & 0.93 & 3.671 & 2.79 & 158 \\
\hline$-1+x, y, z$ & 0.93 & 3.481 & 2.96 & 117 \\
\hline $1+x, y, z$ & 0.97 & 3.788 & 3.05 & 134 \\
\hline $0.5+x, 1.5-y, 0.5+z$ & 0.96 & 3.872 & 3.10 & 139 \\
\hline $0.5+x, 1.5-y, 0.5+z$ & 0.96 & 3.418 & 2.74 & 128 \\
\hline$x, y, z$ & 1.08 & $2.614(3)$ & 1.57 & 162 \\
\hline$x, y, z$ & 0.91 & $2.787(3)$ & 1.97 & 148 \\
\hline$x, y, z$ & 0.91 & $3.054(9)$ & 2.16 & 166 \\
\hline$-0.5-x,-0.5+y, 0.5-z$ & 0.93 & $3.329(4)$ & 2.45 & 158 \\
\hline$-0.5+x, 0.5-y,-0.5+z$ & 0.93 & $3.478(5)$ & 2.63 & 152 \\
\hline $0.5+x, 0.5-y,-0.5+z$ & 0.97 & $3.437(4)$ & 2.58 & 147 \\
\hline$-1+x, y, z$ & 0.93 & 3.550 & 2.85 & 133 \\
\hline$-x,-y,-z$ & 0.96 & 3.637 & 2.77 & 151 \\
\hline $1+x, y, z$ & 0.97 & 3.701 & 2.82 & 152 \\
\hline $0.5-x,-0.5+y, 0.5+z$ & 0.96 & 3.584 & 2.80 & 139 \\
\hline $0.5-x,-0.5+y, 0.5+z$ & 0.96 & 3.594 & 2.82 & 139 \\
\hline $0.5-x,-0.5+y, 0.5+z$ & 0.96 & 3.410 & 2.56 & 148 \\
\hline
\end{tabular}

$\mathrm{O}(1)-\mathrm{H}(1 \mathrm{O}) \cdots \mathrm{O}(8)$

$\mathrm{O}(15)-\mathrm{H}(15 \mathrm{O}) \cdots \mathrm{O}(22)$

$\mathrm{C}(34)-\mathrm{H}(34 \mathrm{~A}) \cdots \mathrm{O}(1 \mathrm{G})$

$\mathrm{C}(17)-\mathrm{H}(17) \cdots \mathrm{O}(42)$

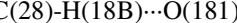

$\mathrm{O}(1)-\mathrm{H}(1 \mathrm{O}) \cdots \mathrm{O}(8)$

$\mathrm{O}(15)-\mathrm{H}(15 \mathrm{O}) \cdots \mathrm{O}(22)$

$\mathrm{C}(5)-\mathrm{H}(5) \cdots \mathrm{O}(181)$

$\mathrm{C}(14)-\mathrm{H}(14 \mathrm{~B}) \cdots \mathrm{O}(41)$

$\mathrm{C}(33)-\mathrm{H}(33 \mathrm{C}) \cdots \mathrm{O}(35)$

(37)-H(37B) $\cdots \mathrm{O}(35)$

(3G) $-\mathrm{H}(3 \mathrm{G}$ centroid $\mathrm{D}$

$\mathrm{O}(1)-\mathrm{H}(1 \mathrm{O}) \cdots \mathrm{O}(22)$

$\mathrm{O}(15)-\mathrm{H}(15 \mathrm{O}) \cdots \mathrm{O}(8)$

(3)-H(3)‥ $\mathrm{O}(182)$

$\mathrm{C}(5)-\mathrm{H}(5) \cdots \mathrm{O}(181)$

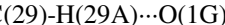

- $\mathrm{H}(34 \mathrm{~B}) \cdots \mathrm{O}(1 \mathrm{G})$

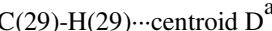

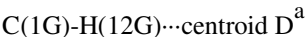

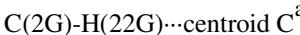

$\mathrm{C}(17)-\mathrm{H}(17) \cdots \mathrm{O}(42)$

$\mathrm{C}(21)-\mathrm{H}(21 \mathrm{~B}) \cdots \mathrm{O}(41)$

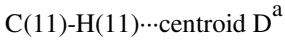

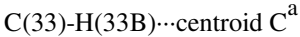

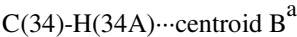





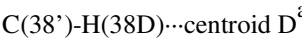

Symmetry

D-

0.94

0.94

0.97

0.93

0.97

0.97

0.96

0.96

2.791(3)

$3.494(6)$

$3.538(5)$

$3.325(4)$

$3.144(4)$

$3.250(6)$

3.566

3.660

Angle ( ${ }^{\circ}$

D-H $\cdots A$ $2.5-x, 0.5+y, 0.5-z$

$0.5+x, 0.5-y,-0.5+z$

$-0.5+x, 0.5-y,-0.5+z$

$1+x, y, z$

$1-x, 1-y,-z$

$1.5-x, 0.5+y, 0.5-z$

$1.5-x, 0.5+y, 0.5-z$

$1.5-x, 0.5+y, 0.5-z$

$x, 0.5+y,-0.5-z$

$.5-x,-0.5+y,-0.5-z$

$-1+x, y, z$

$0.5+x, 1.5-y, 0.5+z$

0.91

0.91
0.93

0.97

0.93

0.97

0.96

0.97

0.96

0.96

0.96

2.703(2)

2.791(2)

$3.408(3)$

$3.169(4)$

$3.426(5)$

$3.456(9)$

3.492

3.614

2.65

2.66

146

172

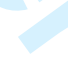


2

3

4

5

6

7

8

TABLE IV Packing coefficients and related features for compounds 1a-ded. ${ }_{--}$

\begin{tabular}{|c|c|c|c|c|c|}
\hline Compound & $\begin{array}{c}\mathbf{1 a} \\
\mathbf{1} \cdot \text { acetone } \\
(1: 1)\end{array}$ & $\begin{array}{c}\text { 1b } \\
\text { 1.DMF } \\
(1: 1)\end{array}$ & $\begin{array}{c}\text { 1c } \\
\text { 1·DMSO } \\
(1: 1)\end{array}$ & $\begin{array}{c}\text { 1d } \\
\mathbf{1} \cdot n-\mathrm{BuOH} \\
(2: 1)\end{array}$ & \\
\hline Unit cell volume $/ \AA^{3}$ & 3697.4 & 3773.5 & 3746.3 & 3610.2 & \\
\hline Crystal packing coefficient $/ \%$ & 67.2 & 68.1 & 67.0 & 67.2 & \\
\hline $\begin{array}{l}\text { Estimated space occupied by the host } \\
\text { framework } 1 \%\end{array}$ & 60.9 & 59.4 & 59.9 & 62.3 & \\
\hline Potential solvent-accessible space $1 \%$ & 11.5 & 16.5 & 12.3 & 12.6 & Deleted: solvent \\
\hline $\begin{array}{l}\text { Potential solvent-accessible volume per } \\
\text { unit cell } / \bar{\AA}^{3}\end{array}$ & 424.1 & 623.3 & $\underline{462.4}$ & 454.5 & Deleted: solvent \\
\hline $\begin{array}{l}\text { Estimated space occupied by the guest } \\
\text { molecules } / \%\end{array}$ & 6.3 & 8.7 & 7.1 & 4.9 & \\
\hline $\begin{array}{l}\text { Estimated volume per unit cell occupied } \\
\text { by the guests } / \AA^{3}\end{array}$ & 233 & 328 & 266 & 177 & \\
\hline
\end{tabular}


Table V Cell similarity indices $(\pi)$, and isostructurality $\mathrm{I}(s)$ and isometricity $\mathrm{I}(m)$ parameters of the host frameworks, calculated for compounds 1a-d . $^{\mathrm{a}}$

\begin{tabular}{|c|c|c|c|c|c|}
\hline \multirow{2}{*}{$\begin{array}{l}\text { Compared } \\
\text { compounds }\end{array}$} & \multirow[b]{2}{*}{$\pi$} & \multicolumn{2}{|c|}{ Superimposing 38 atoms } & \multicolumn{2}{|c|}{ Superimposing 50 atoms } \\
\hline & & $\mathrm{I}(s)(\%)$ & $\mathrm{I}(m)(\%)$ & $\mathrm{I}(s)(\%)$ & $\mathrm{I}(m)(\%)$ \\
\hline 1a-1b & 0.015 & 55.04 & 96.87 & 33.72 & 88.18 \\
\hline 1a-1c & 0.008 & 23.56 & 99.61 & 23.24 & 87.70 \\
\hline $1 b-1 c$ & 0.023 & 16.92 & 98.05 & 17.91 & 85.86 \\
\hline $1 \mathrm{a}-1 \mathrm{~d} \mathbf{1}^{\mathrm{c}}$ & 0.018 & - & 74.69 & - & 12.71 \\
\hline $1 \mathrm{a}-1 \mathrm{~d} 2^{\mathrm{c}}$ & 0.018 & - & 74.69 & - & 12.93 \\
\hline $1 b-1 d 1^{c}$ & 0.034 & - & 71.64 & - & 1.19 \\
\hline $1 b-1 d 2^{c}$ & 0.034 & - & 71.64 & - & 1.61 \\
\hline $1 \mathrm{c}-1 \mathrm{~d} 1^{\mathrm{c}}$ & 0.011 & - & 79.04 & - & 16.48 \\
\hline $1 \mathrm{c}-1 \mathrm{~d} 2^{\mathrm{c}}$ & 0.011 & - & 79.04 & - & 16.84 \\
\hline $1 \mathrm{~d} 1-1 \mathrm{~d} 2^{\mathrm{c}}$ & - & 100 & 100 & 77.60 & 98.68 \\
\hline
\end{tabular}

${ }^{a}$ Calculated following Kálmán et al. [10-12].

| ${ }^{\mathrm{b}}$ In the calculation of the $\mathrm{I}(\mathrm{s})$ and $\mathrm{I}(\mathrm{m})$ indices, either only the more rigid parts of the calix[4]arene molecule (i.e. 38 non-hydrogen atom positions) were fitted, or all 50 non-H atoms for each molecule (including also the mobile ester substituents) were taken into account.

${ }^{c}$ Due to the static disorder of the terminal ethyl group in one of the pendant ester substituents in 1d, two conformers of that host, one denoted $1 \mathbf{1 d}$ [having $~ 2 / 3$ probability, containing C(37)-C(38)], and a second one denoted $1 \mathbf{d} 2$ [with $\sim 1 / 3$ probability, containing $\mathrm{C}\left(37^{\prime}\right)-\mathrm{C}\left(38^{\prime}\right)$ ], have been compared with the calixarene hosts in compounds $\mathbf{1} \mathbf{a}-\mathbf{c}$. 
1

2

3

4

5

6

7

8

9

10

11

12

13

14
Captions to Scheme and Figures

SCHEME 1 Compounds 1a-d.

FIGURE 1 Perspective view of the 1:1 host-guest units of compounds 1a [1.acetone

Deleted: host-guest (1:1)] (a), 1b [1.DMF (1:1)] (b), and 1c [1.DMSO (1:1)] (c). The displacement ellipsoids are drawn at $30 \%$ probability level. Dashed lines represent hydrogen bonds.

FIGURE 2 Packing illustration of $\mathbf{1 a}[\mathbf{1} \cdot$ acetone $(1: 1)]$, viewed along the $a_{k}$ axis.

Deleted:

Deleted:

FIGURE 3 Packing motif of $\mathbf{1 b}[\mathbf{1} \cdot \mathrm{DMF}(1: 1)]$, viewed along the $c_{\mathbf{k}}$ axis.

Deleted: -

FIGURE 4 Packing motif of 1c [1·DMSO (1:1)], viewed along the $a_{-}$axis.

Deleted: host-guest

FIGURE 5 Perspective view of the H-bonded host-guest unit of compound 1d [1.

$\mathrm{BuOH}(2: 1)]$. Displacement ellipsoids are drawn at $30 \%$ probability level. Dashed lines represent hydrogen bonds.

FIGURE 6 Disorder model of the skeleton of the $n$-BuOH guest in $1 \mathbf{d}[1 \cdot n-\mathrm{BuOH}$

Deleted: the (2:1)].

FIGURE 7 Packing illustration of $\mathbf{1 d}[\mathbf{1} \cdot n-\mathrm{BuOH}(2: 1)]$, viewed along the $a_{2}$ axis.

Deleted:

FIGURE 8 Illustration of the position of the calix[4]arene host molecules in each of the unit cells of compounds $\mathbf{1 a}(\mathrm{a}), \mathbf{1 b}(\mathrm{b}), \mathbf{1 c}(\mathrm{c})$ and $\mathbf{1 d}(\mathrm{d})$, viewed down the $c_{\mathrm{k}}$ axis. The location of the host in $\mathbf{1 d}$ is related to those in 1a-c by a virtual, nonDeleted: respectively, Deleted: crystallographic twofold symmetry (due to a $180^{\circ}$ rotation), thus indicating a morphotropic relationship. 


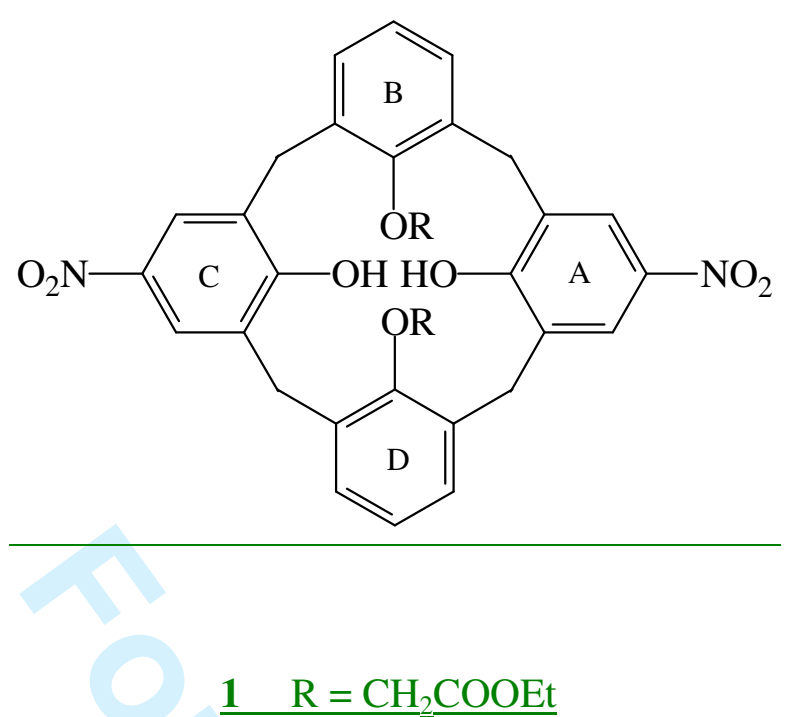

Formatted: Bullets and Numbering

1a 1.Acetone (1:1)

1b 1.DMF (1:1)

1c 1.DMSO (1:1)

$\underline{1 d \quad 1 \cdot n-\mathrm{BuOH}(2: 1)}$

SCHEME 1 

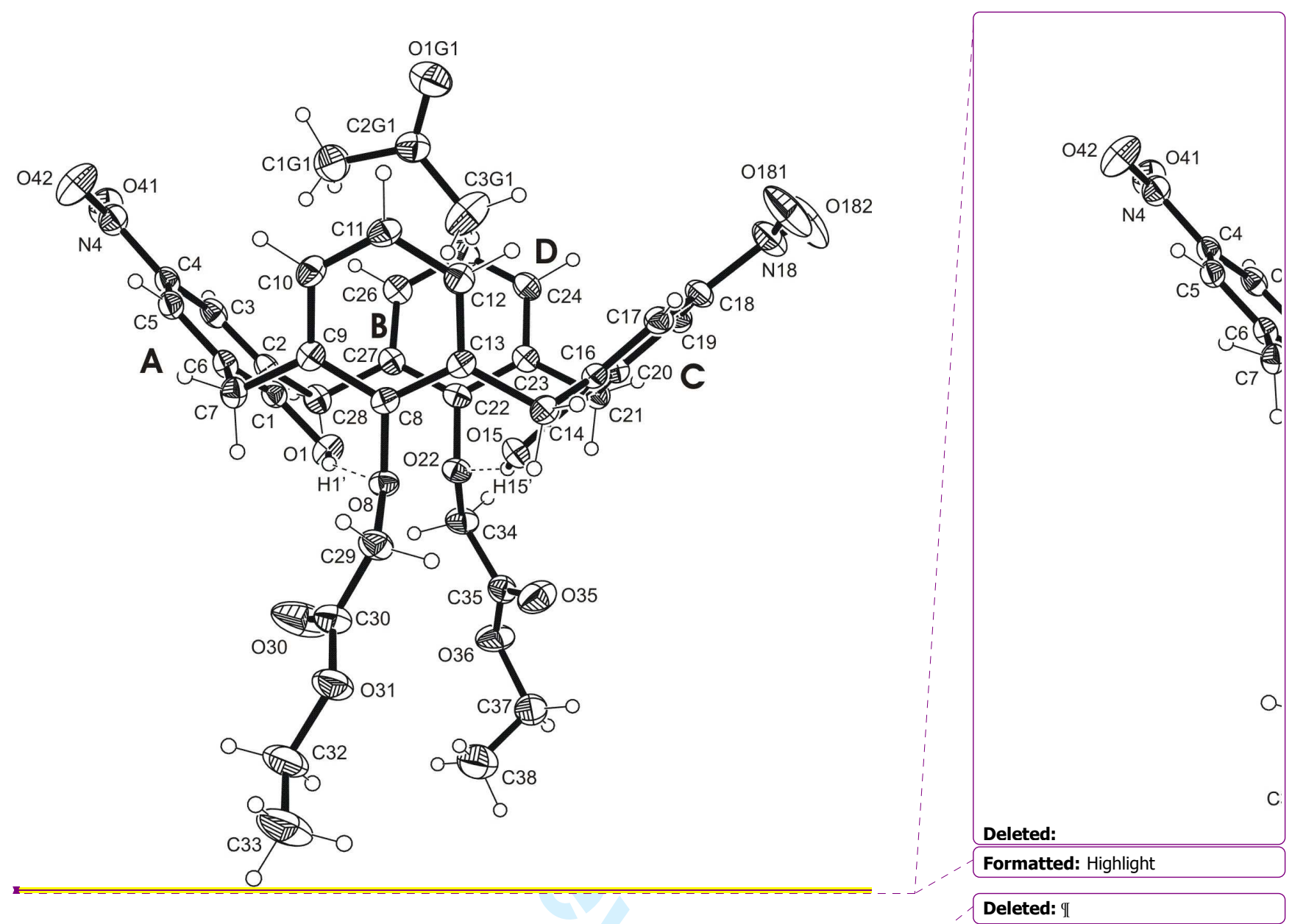

FIGURE 1a 


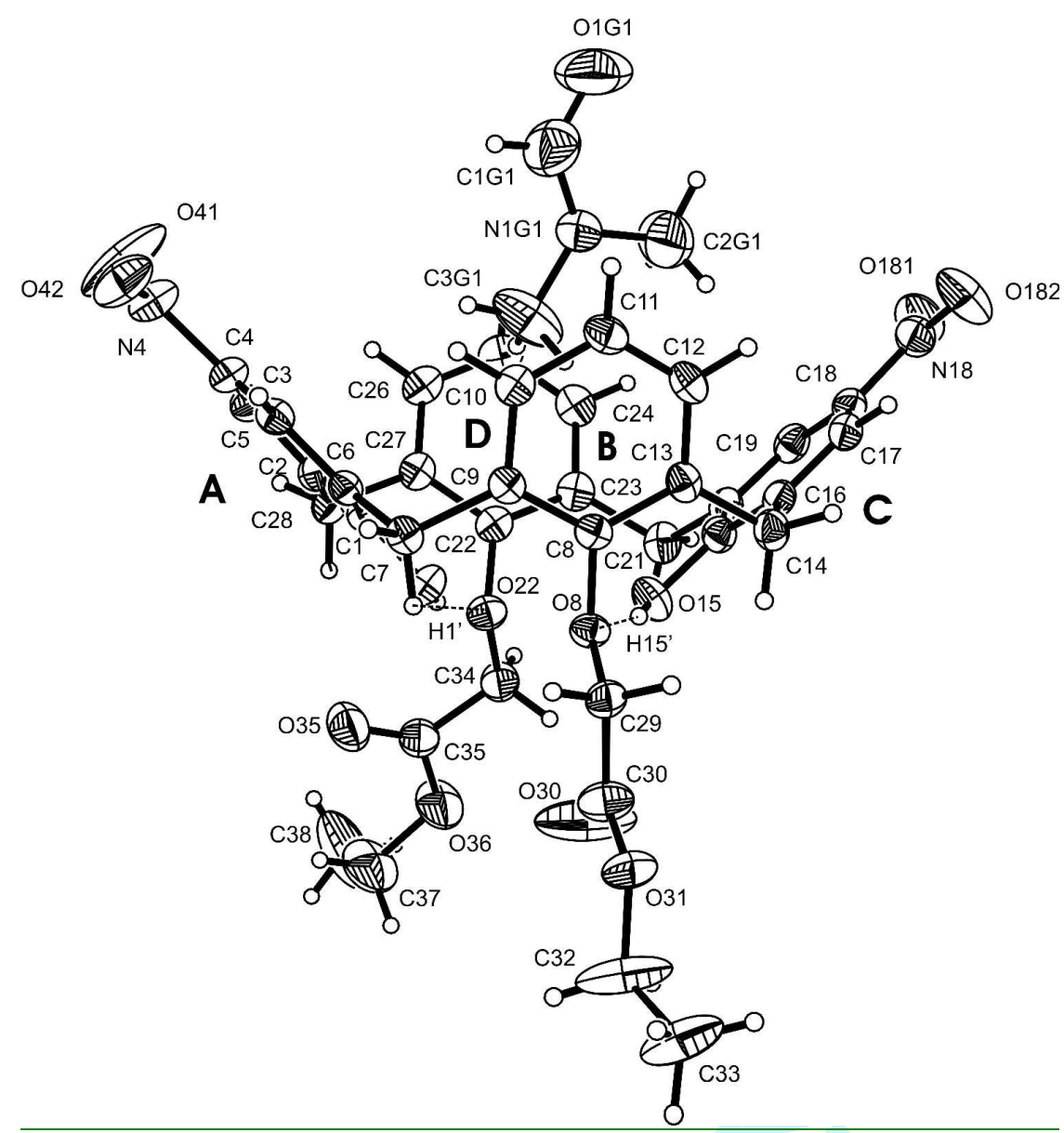

FIGURE 1b 


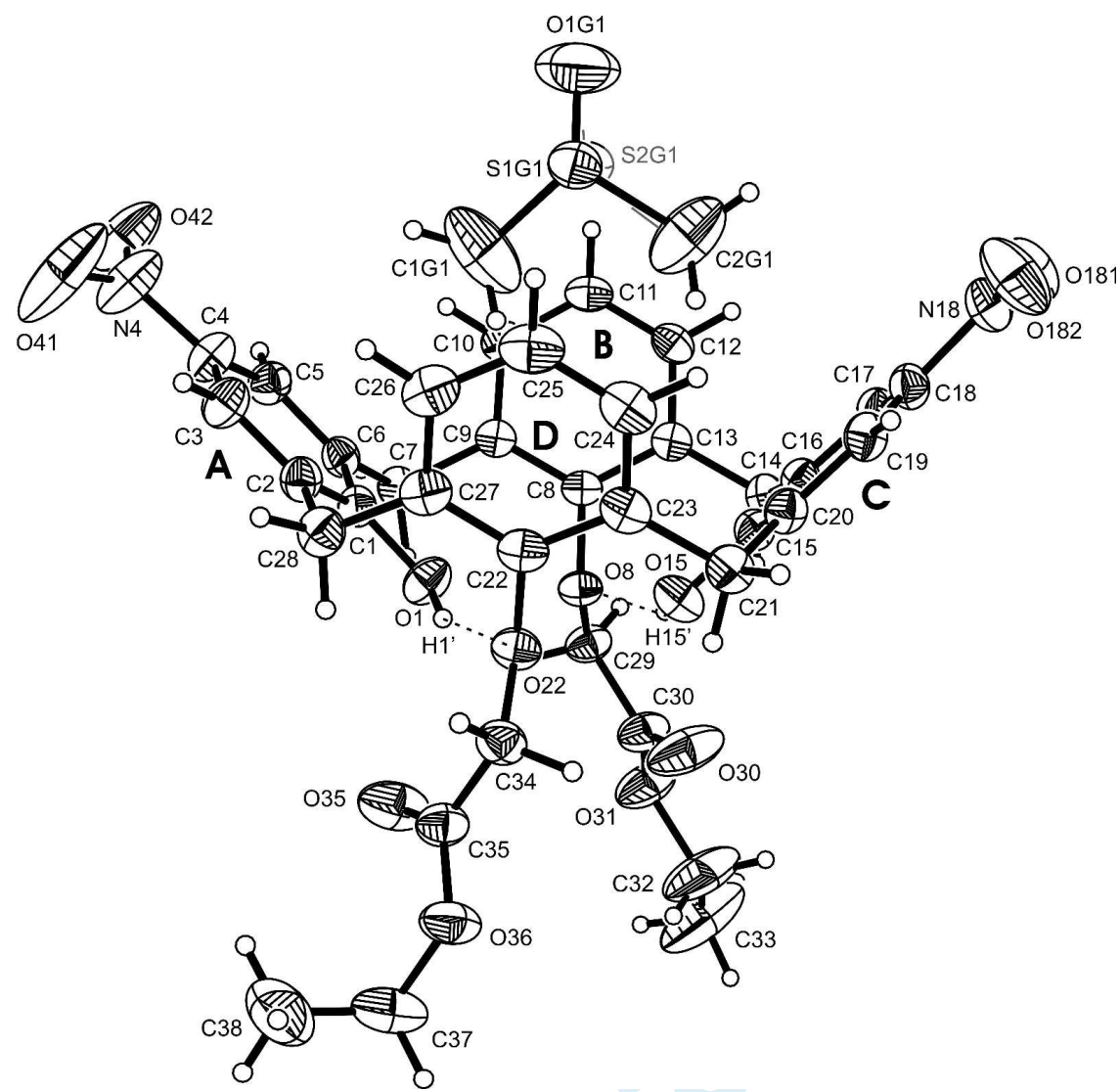

$\underline{\text { FIGURE 1c }}$ 


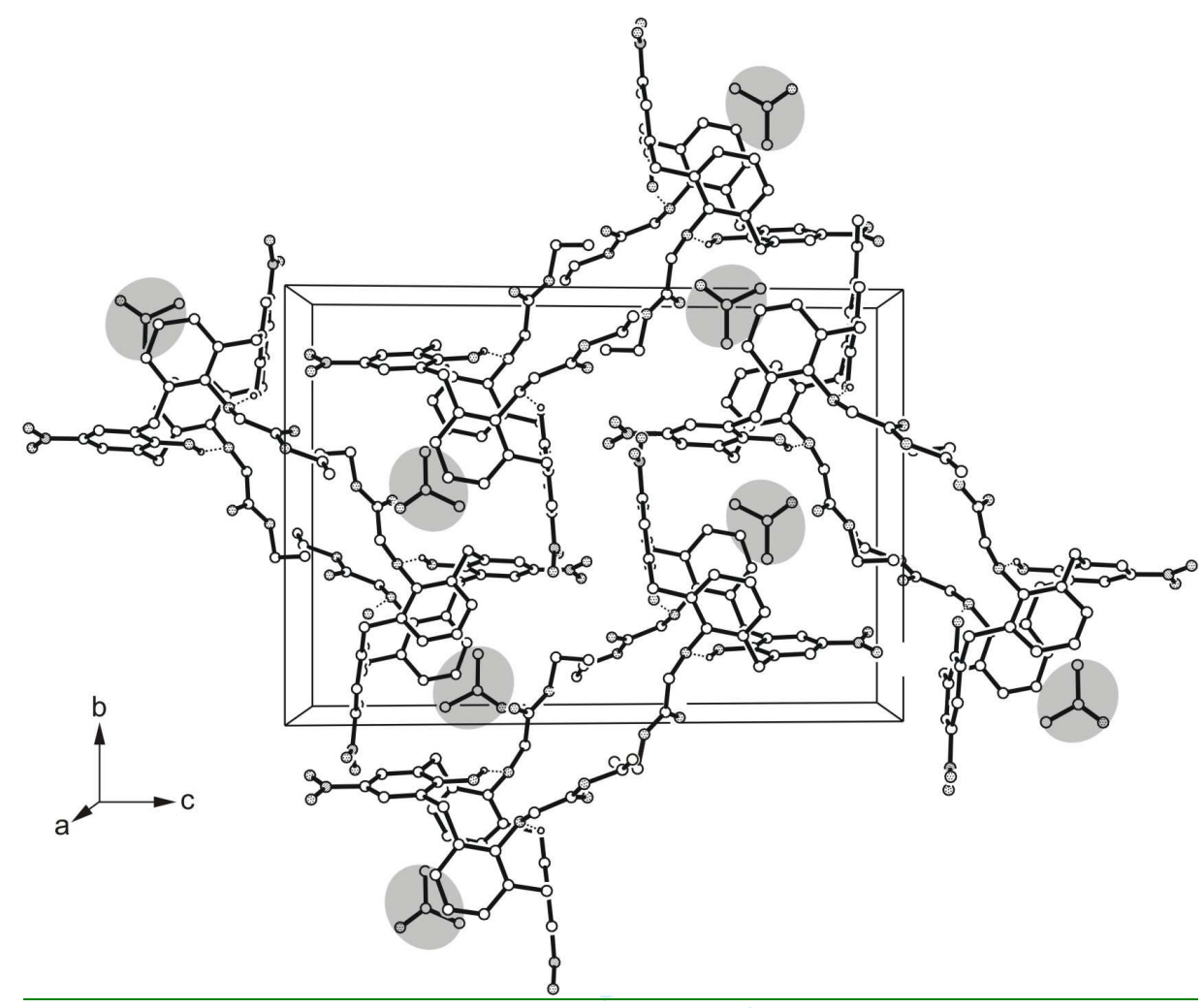

FIGURE 2 

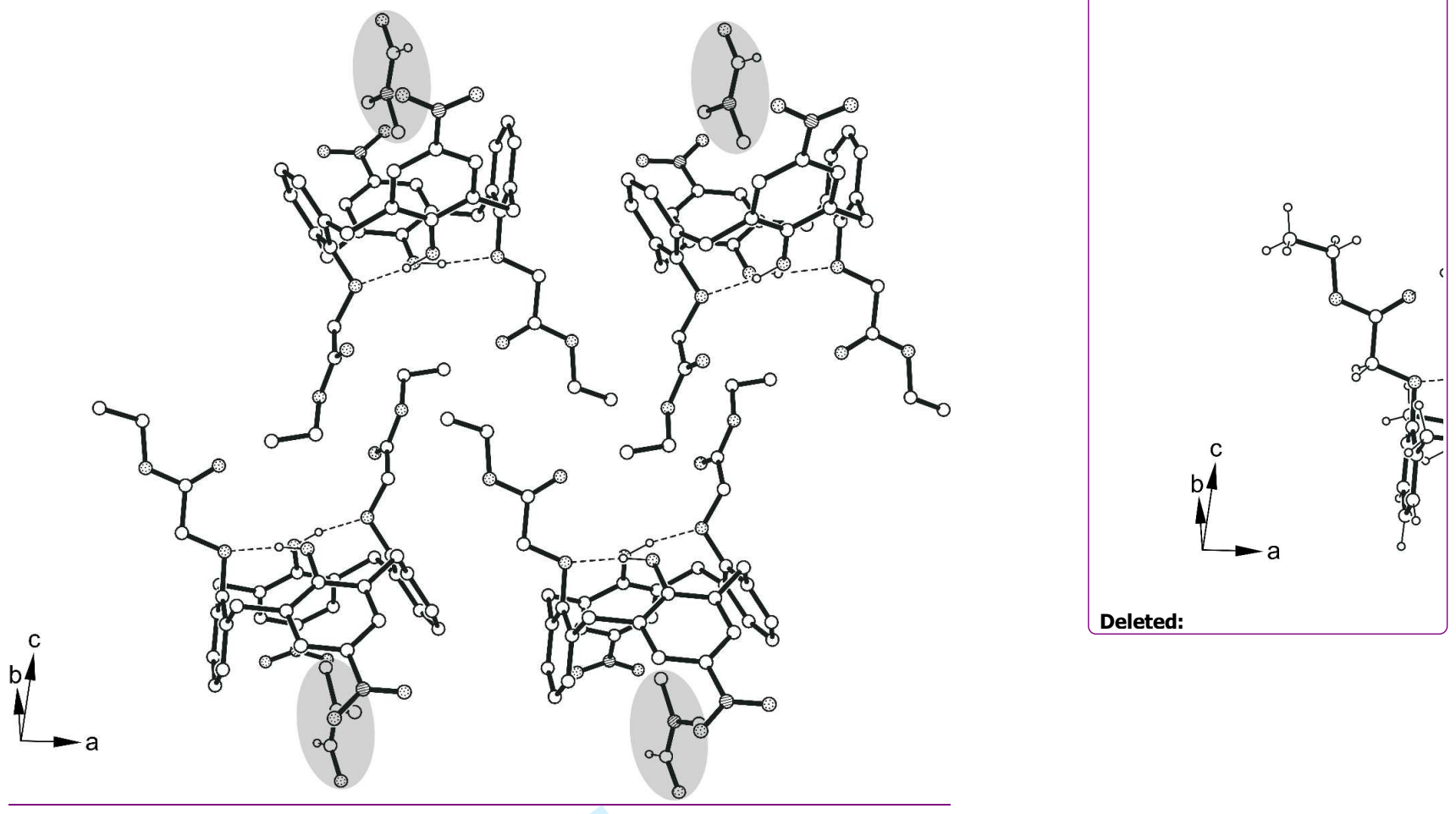

\section{FIGURE 3}

Formatted: Highlight 


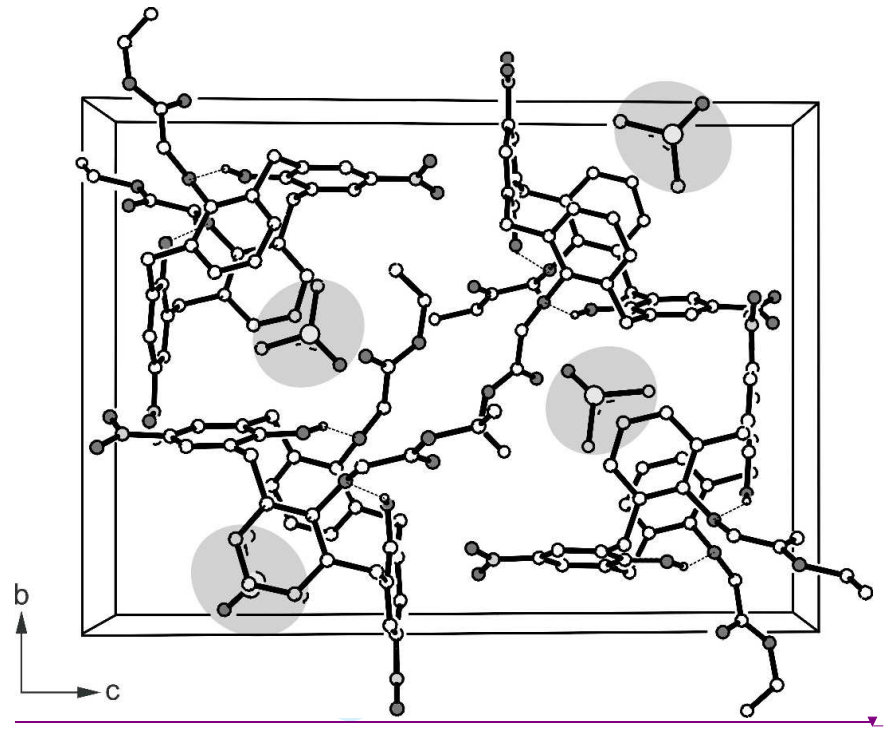

FIGURE 4

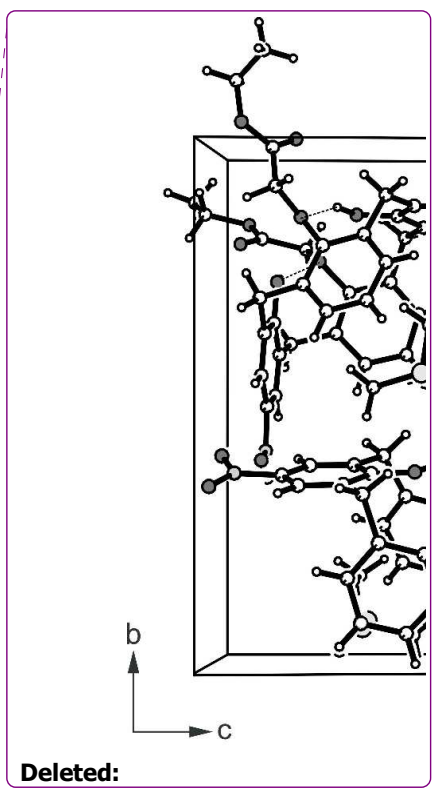

Formatted: Highlight 
FIGURE 6 


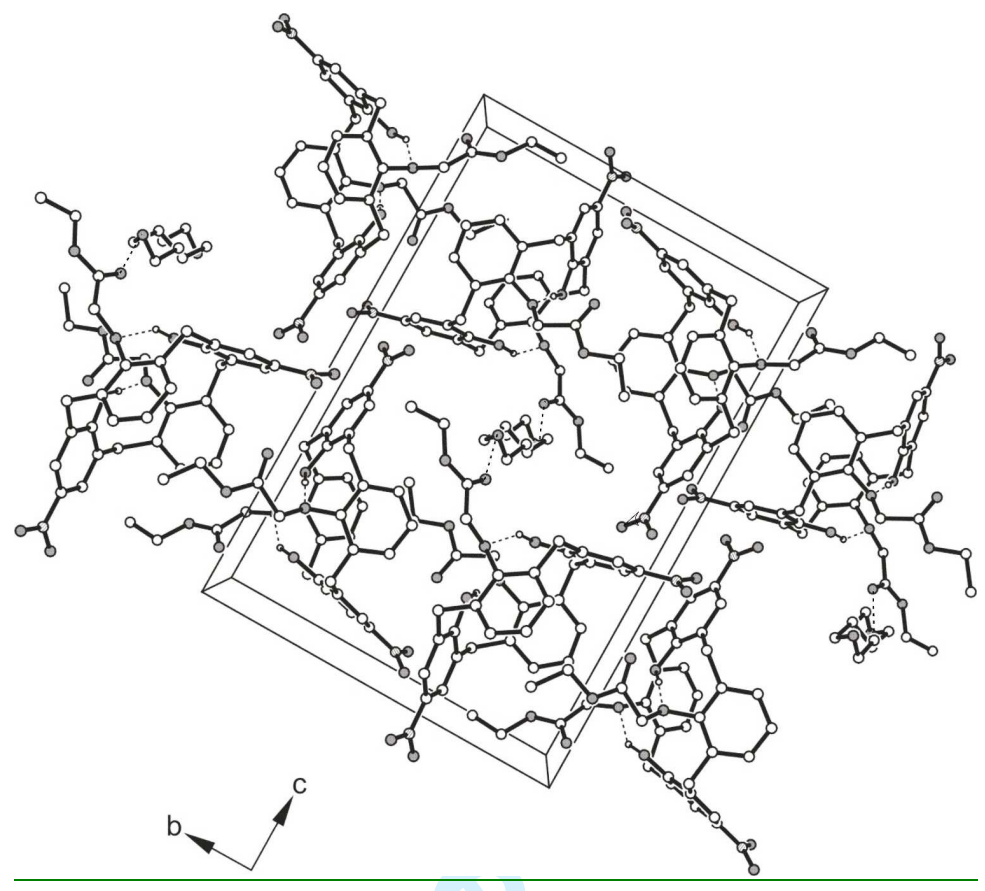

FIGURE 7 


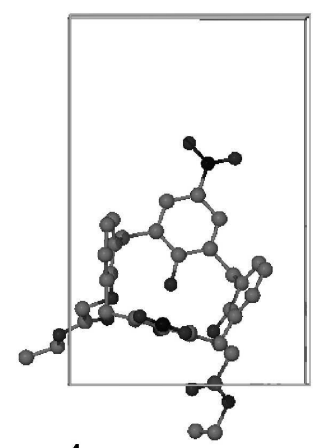

$1 a$

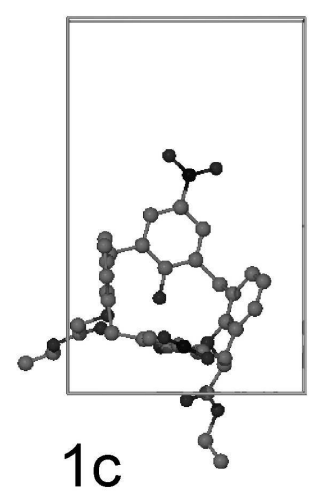

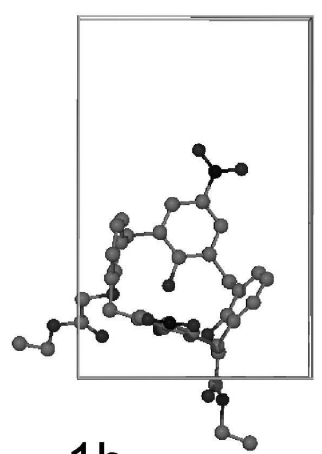

$1 b$

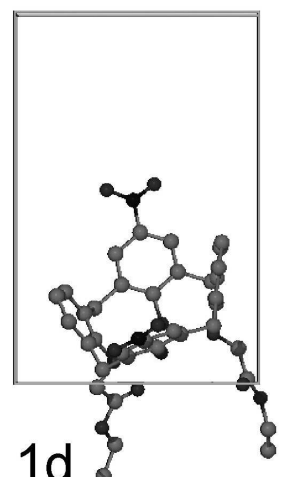


Page 8: [1] Formatted

gruber

5/10/2006 3:01:00 PM

Font: (Default) Times New Roman, 12 pt, Complex Script Font: Times New Roman, 12 $\mathrm{pt}$

Page 8: [2] Formatted

gruber

5/10/2006 3:01:00 PM

Font: (Default) Times New Roman, 12 pt, Complex Script Font: Times New Roman, 12 pt, Not Bold

Page 8: [3] Formatted $\quad$ gruber $\quad 5 / 10 / 2006$ 3:01:00 PM

Font: (Default) Times New Roman, 12 pt, Complex Script Font: Times New Roman, 12 $\mathrm{pt}$

Page 8: [4] Formatted $\quad$ gruber $\quad$ 5/10/2006 3:01:00 PM

Font: (Default) Times New Roman, 12 pt, Complex Script Font: Times New Roman, 12 pt, Not Bold

Page 8: [5] Formatted $\quad$ gruber $\quad$ 5/10/2006 3:01:00 PM

Font: (Default) Times New Roman, 12 pt, Complex Script Font: Times New Roman, 12 $\mathrm{pt}$

Page 8: [6] Formatted gruber

5/10/2006 3:01:00 PM

Font: (Default) Times New Roman, 12 pt, Complex Script Font: Times New Roman, 12 pt, Not Bold

Page 8: [7] Formatted

gruber

5/10/2006 3:01:00 PM

Font: (Default) Times New Roman, 12 pt, Complex Script Font: Times New Roman, 12 $\mathrm{pt}$

Page 8: [8] Formatted

gruber

5/10/2006 3:01:00 PM

Font: (Default) Times New Roman, 12 pt, Complex Script Font: Times New Roman, 12 pt, Not Bold

Page 8: [9] Formatted $\quad$ gruber $\quad$ 5/10/2006 3:01:00 PM

Font: (Default) Times New Roman, 12 pt, Complex Script Font: Times New Roman, 12 $\mathrm{pt}$

Page 9: [10] Formatted

gruber

5/10/2006 3:01:00 PM

Font: (Default) Times New Roman, 12 pt, Complex Script Font: Times New Roman, 12 pt, Not Bold

Page 9: [11] Formatted $\quad$ gruber $\quad$ 5/10/2006 3:01:00 PM

Font: (Default) Times New Roman, 12 pt, Complex Script Font: Times New Roman, 12 $\mathrm{pt}$

Page 9: [12] Formatted $\quad$ gruber $\quad$ 5/10/2006 3:01:00 PM

Font: (Default) Times New Roman, 12 pt, Complex Script Font: Times New Roman, 12 pt, Not Bold

Page 9: [13] Formatted $\quad$ gruber $\quad$ 5/10/2006 3:01:00 PM

Font: (Default) Times New Roman, 12 pt, Complex Script Font: Times New Roman, 12 $\mathrm{pt}$

Page 9: [14] Formatted $\quad$ gruber $\quad$ 5/10/2006 3:01:00 PM

Font: (Default) Times New Roman, 12 pt, Complex Script Font: Times New Roman, 12 pt, Not Bold 
Font: (Default) Times New Roman, 12 pt, Complex Script Font: Times New Roman, 12 $\mathrm{pt}$

Page 9: [16] Formatted

gruber

5/10/2006 3:01:00 PM

Font: (Default) Times New Roman, 12 pt, Complex Script Font: Times New Roman, 12 pt, Not Bold

Page 9: [17] Formatted $\quad$ gruber $\quad 5 / 10 / 2006$ 3:01:00 PM

Font: (Default) Times New Roman, 12 pt, Complex Script Font: Times New Roman, 12 $\mathrm{pt}$

Page 9: [18] Formatted $\quad$ gruber $\quad$ 5/10/2006 3:01:00 PM

Font: (Default) Times New Roman, 12 pt, Complex Script Font: Times New Roman, 12 pt, Not Bold

Page 9: [19] Formatted $\quad$ gruber $\quad$ 5/10/2006 3:01:00 PM

Font: (Default) Times New Roman, 12 pt, Complex Script Font: Times New Roman, 12 $\mathrm{pt}$

Page 9: [20] Comment [SW2]

5/10/2006 2:58:00 PM

Är detta den avsedda betydelsen?

Page 9: [21] Deleted

ics

3/27/2006 3:06:00 PM

Hence, according to the isostructurality calculations, inclusion of the protic, elongated

butanol guests, particularly those with the flexible pendant ester chains, seriously affects

also the conformation of the calixarene host

Page 9: [22] Formatted

gruber

5/10/2006 3:01:00 PM

Font: (Default) Times New Roman, 12 pt, Complex Script Font: Times New Roman, 12 pt, Not Bold

Page 9: [23] Deleted Sven Westman

, particularly those of the flexible pendant ester chains

3/27/2006 12:09:00 PM

Font: (Default) Times New Roman, 12 pt, Complex Script Font: Times New Roman, 12 pt

\section{Page 9: [25] Formatted}

gruber

5/10/2006 3:01:00 PM

Font: (Default) Times New Roman, 12 pt, Complex Script Font: Times New Roman, 12 pt, Not Bold

\begin{tabular}{lll}
\hline Page 9: [26] Formatted & gruber & 5/10/2006 3:01:00 PM
\end{tabular}
Font: (Default) Times New Roman, 12 pt, Complex Script Font: Times New Roman, 12 $\mathrm{pt}$

Page 9: [27] Formatted gruber $\quad$ 5/10/2006 3:01:00 PM

Font: (Default) Times New Roman, 12 pt, Complex Script Font: Times New Roman, 12 pt, Not Bold 
Font: (Default) Times New Roman, 12 pt, Complex Script Font: Times New Roman, 12 $\mathrm{pt}$

Page 9: [29] Formatted gruber $\quad$ 5/10/2006 3:01:00 PM

Font: (Default) Times New Roman, 12 pt, Complex Script Font: Times New Roman, 12 pt, Not Bold

Page 9: [30] Formatted $\quad$ gruber $\quad$ 5/10/2006 3:01:00 PM

Font: (Default) Times New Roman, 12 pt, Complex Script Font: Times New Roman, 12 $\mathrm{pt}$

Page 9: [31] Formatted $\quad$ gruber $\quad 5 / 10 / 2006$ 3:01:00 PM

Font: (Default) Times New Roman, 12 pt, Complex Script Font: Times New Roman, 12 pt, Not Bold

Page 9: [32] Formatted gruber $\quad$ 5/10/2006 3:01:00 PM

Font: (Default) Times New Roman, 12 pt, Complex Script Font: Times New Roman, 12 $\mathrm{pt}$

Page 9: [33] Formatted gruber 5/10/2006 3:01:00 PM

Font: (Default) Times New Roman, 12 pt, Complex Script Font: Times New Roman, 12 pt, Not Bold

Page 9: [34] Formatted gruber 5/10/2006 3:01:00 PM

Font: (Default) Times New Roman, 12 pt, Complex Script Font: Times New Roman, 12 $\mathrm{pt}$

Page 9: [35] Formatted gruber 5/10/2006 3:01:00 PM

Font: (Default) Times New Roman, 12 pt, Complex Script Font: Times New Roman, 12 pt, Not Bold

Page 9: [36] Formatted gruber
5/10/2006 3:01:00 PM

Font: (Default) Times New Roman, 12 pt, Complex Script Font: Times New Roman, 12 $\mathrm{pt}$

Page 9: [37] Formatted gruber 5/10/2006 3:01:00 PM Font: (Default) Times New Roman, 12 pt, Complex Script Font: Times New Roman, 12 pt, Not Bold

Page 9: [38] Formatted $\quad$ gruber $\quad$ 5/10/2006 3:01:00 PM
Font: (Default) Times New Roman, 12 pt, Complex Script Font: Times New Roman, 12 $\mathrm{pt}$

Page 9: [39] Formatted $\quad$ gruber $\quad 5 / 10 / 2006$ 3:01:00 PM Font: (Default) Times New Roman, 12 pt, Complex Script Font: Times New Roman, 12 pt, Not Bold

Page 9: [40] Formatted $\quad$ gruber $\quad$ 5/10/2006 3:01:00 PM

Font: (Default) Times New Roman, 12 pt, Complex Script Font: Times New Roman, 12 $\mathrm{pt}$

Page 9: [41] Formatted $\quad$ gruber $\quad$ 5/10/2006 3:01:00 PM

Font: (Default) Times New Roman, 12 pt, Complex Script Font: Times New Roman, 12 pt, Not Bold 
Font: (Default) Times New Roman, 12 pt, Complex Script Font: Times New Roman, 12 pt

Page 9: [43] Formatted $\quad$ gruber $\quad \mathbf{5 / 1 0 / 2 0 0 6 ~ 3 : 0 1 : 0 0 ~ P M ~}$ Font: (Default) Times New Roman, 12 pt, Complex Script Font: Times New Roman, 12 pt, Not Bold

Page 9: [44] Formatted $\quad$ gruber $\quad$ 5/10/2006 3:01:00 PM
Font: (Default) Times New Roman, 12 pt, Complex Script Font: Times New Roman, 12 $\mathrm{pt}$ Page 9: [45] Formatted $\quad$ gruber $\quad 5 / 10 / 2006$ 3:01:00 PM Font: (Default) Times New Roman, 12 pt, Complex Script Font: Times New Roman, 12 pt, Not Bold 